DOI https://doi.org/10.36059/978-966-397-130-8/142-155

\title{
COMPETENCE APPROACH IN TECHNOLOGIES IMPLEMENTATION OF THE CHILDREN AND PARENTS SOCIAL EDUCATION WHO ARE IN DIFFICULT LIFE CIRCUMSTANCES OR HAVE THE HIGHEST RISK OF GETTING INTO THEM
}

\author{
Sushyk N. S., Karpinska N. V.
}

\section{INTRODUCTION}

The primary children's socialization and the parent's secondary socialization occur under the influence of favorable and unfavorable factors of the social environment. According to the author's position, a family is a small, social, dynamic, multifunctional group of people based on marriage, blood relationship, family relations, adoption or other form of children's placement such as guardianship, care, patronage, whose members live together connected by common life as well as mutual moral and material responsibility, homogeneity in formation and satisfaction of socio-cultural, socio-economic and other needs characterized by a set of social roles, norms, rules, behavior patterns, rights and responsibilities that govern the relationship between spouses, parents and children, siblings and other relatives.

According to the Procedure for the provision of social services to the families in difficult life circumstances such families include the ones that cannot independently overcome the negative impact of circumstances caused by the following factors: 1) old age; 2) partial or complete loss of motor activity, memory; 3) both incurable diseases and long-term treatment illnesses; 4) mental and behavioral disorders including those related to the psychoactive substances use; 5) disability; 6) homelessness; 7) unemployment; 8) poverty; 9) behavioral disorders in children due to parental divorce; 10) evasion the responsibilities in relation to the child upbringing by parents or persons replacing them; 11) loss of social ties including while in places of imprisonment; 12) child abuse; 13) domestic violence; 14) gender-based violence; 15) getting into a situation of human 
trafficking; 16) damage caused by fire, natural disaster, catastrophe, hostilities, terrorist act, armed conflict, temporary occupation ${ }^{1}$.

According to the Procedure of the Social Services Provision to families at the highest risk to get into difficult life circumstances due to adverse external and / or internal factors such families include: 1) families in which children are taken away from their parents without deprivation of their parental rights; 2) families where the process of parental divorce is taking place and the dispute between the mother and the father regarding the determination of the children place of residence and the participation of the parents in their upbringing is being resolved; 3) families with children where the parents long-term illness prevents them from fulfilling their parental responsibilities; 4) families with children with disabilities and families with children whose parents have disabilities; 5) families whose parents have their parental rights restored; 6) families with children where the parents are migrant workers; 7) low-income families with children; 8) families whose children exposed to institutional care; 9) families from which children are placed in the family of a foster parent; 10) families in which children systematically leave their place of residence arbitrarily; 11) families in which children do not regularly attend educational institutions without good reason ${ }^{2}$.

As a result of adverse social factors the families, children and parents are in difficult life circumstances or have the highest risk of getting into them which negatively affects their various activities.

\section{Types, purpose, tasks, principles of social work with families, children and parents who are in difficult life circumstances or have the highest risk of getting into them}

Article 1 of the Law of Ukraine "On Social Work with Families, Children and Youth» stipulates that «social work with families, children and youth implies professional activity aimed at preventing, minimizing the negative consequences and overcoming difficult life circumstances of families, children and youth through strengthening their ability to realize their own life potential» ${ }^{3}$.

\footnotetext{
1 Порядок організації надання соціальних послуг, затверджений постановою Кабінету Міністрів України від 1 червня 2020 р. № 587. URL: https://zakon.rada.gov.ua/laws/show/587-2020-\%D0\%BF\#n10 (дата звернення: 18.04.2021).

2 там само.

${ }^{3}$ Про соціальну роботу з сім'ями, дітьми та молоддю:Закон України від 17.01.2019 р. № 2671-VIII. URL: https://zakon.rada.gov.ua/laws/show/2558-14\#Text (дата звернення: 18.04.2021).
} 
According to Paragraph 15 Article 1 of the Law of Ukraine «On Social Services» «difficult life circumstances are the circumstances that adversely affect the life, health and individual development, functioning of the family, which the person / family cannot overcome on their own» ${ }^{4}$.

Social managers, social workers, social work specialists, social educators and other actors carry out various types of social work with families, children and parents who are in difficult life circumstances or have the highest risk of falling into them in order to prevent and overcome such circumstances, in particular: 1) social integration; 2) social adaptation, 3) social education; 4) social support; 5) social counseling; 6) social prevention; 7) social mediation; 8) social rehabilitation and others.

The standards defining the procedure, content, scope, conditions, criteria, quality indicators of social services provision have been developed and approved in order to effectively implement certain types of social work with families, children and parents who are in difficult life circumstances or have the highest risk of getting into them. According to Paragraph 17 of Article 1 of the Law of Ukraine «On Social Services» «social services are viewed as actions aimed at preventing difficult life circumstances, overcoming such circumstances or minimizing their negative consequences for individuals / families who are in them $\rangle^{5}$.

Article 12 of the Law of Ukraine «On Social Work with Families, Children and Youth» substantiates that «the tasks of the subjects of social work with families, children and youth are: 1) participation in the implementation of national, regional and other programs of social support for families, children and youth; 2) provision of social services, social assistance, social support to families, children and youth in order to restore their social functions, implementation of a system of measures to prevent and overcome negative phenomena, prevent families, children and youth from getting into difficult life circumstances; 3 ) implementation of social and preventive work among children and youth, implementation of a system of measures to prevent negative phenomena and overcome them; 4) introduction of state standards of social services, new forms, methods of social work with families, children and youth» ${ }^{6}$.

\footnotetext{
${ }^{4}$ Там само.

${ }_{6}^{5}$ Там само.

6 Про соціальні послуги: Закон України від 17.01.2019 p. № 2671-VIII. URL: https://zakon.rada.gov.ua/laws/show/2671-19\#n482 (дата звернення: 18.04.2021)
} 
Article 3 of the Law of Ukraine «On Social Services» stipulates that «the provision of social services is based on the principles of: 1) respect for human rights, children's rights and the rights of persons with disabilities; 2) humanism; 3) ensuring equal rights and opportunities for women and men; 4) respect for honor and dignity; 5) tolerance; 6) legality; 7) social justice, 8) accessibility and openness, 9) impartiality and security; 10) voluntariness; 11) individual approach; 12) complexity; 13) confidentiality; 14) maximum efficiency and transparency of the use of budget and other funds by social service providers; 15) ensuring a high level of quality of social services» ${ }^{7}$.

Social upbringing of children and parents who are in difficult life circumstances or have the highest risk of getting into them is a type of social work aimed at developing, forming a dynamic, integrated set of personal competencies to prevent and overcome such circumstances.

\section{Goal, tasks, content of children's and parents' social education technologies who are in difficult life circumstances or have the highest risk of getting into them on the basis of the competence approach}

Competence approach is an innovative approach to the technologies implementation of the individual's social education to provide a dynamic, integrated set of competencies (health, communication, life, legal, economic, social and other) of children and parents who are in difficult life circumstances or have the highest the risk of getting into them in order to prevent and overcome such circumstances.

Competence is an ability of an individual to activate, mobilize, and effectively apply values, value orientations, knowledge, attitude, skills, and experience in accordance with the requirements, challenges, and opportunities in a particular context.

Based on the results of the scientific literature studying, domestic experience of social work with families, children and youth on the nature, structure, content of personal competencies, we offer the following definitions:

\footnotetext{
Sushyk Nataliia Competentapproachtorealization of technology of social education of personality. Innovative Approachesto Ensuring the Quality of Education, Scientific Research and Technological Processes : monograph / editedby Magdalena Gawron-Łapuszek, YanaSuchukova. Katowice: Publishing House of University of Technology, 2021. P. 894-895, 1219. URL: http://www.wydawnictwo.wst.pl/uploads/files/ 3ae54f97de8a1480cfb229660e616f25.pdf (дата звернення: 08.04.2021)
} 
- vital competence is the ability of the individual to successfully solve pressing problems at different age stages in all spheres of life, to direct social and personal resources to self-improvement (self-knowledge, selfdevelopment, self-education, self-education);

- health-preserving competence is the ability of an individual to apply an integrated set of health-preserving competencies in certain conditions in order to achieve full physical, mental, spiritual, social wellbeing;

- communicative competence is the ability of an individual to communicate tolerantly and effectively with people in different life situations;

- legal competence is the ability of an individual to responsibly, effectively implement rights and responsibilities in all spheres of life;

- economic competence is the ability of the individual to responsibly earn, store, save, rationally use financial, material, personal, family, social resources;

- social competence is the ability of an individual to work effectively with partners in a group, team, team, perform various social roles and functions («citizen», «employee», «pupil», «student», «husband / wife», «father / mother» and other) ${ }^{8}$.

- parental competence is a dynamic, complex characteristic of personality, which provides for the formation of a system of values, value orientations, knowledge, skills, ability to perform quality functions of parents in relation to birth, care, development, communication, education, upbringing, protection of children in educational, upbringing, practical activities.

In order to provide social support to families who are in difficult life circumstances or have the highest risk of falling into them, social managers, social workers, specialists in social work, social pedagogues, parents and children based on partnership implement technologies of social education aimed at development, formation of an integrated set of personal competencies, in particular:

\footnotetext{
Сушик Н. С. Формування здоров'язбережувальної компетентності особистості у реалізації технологій соціального виховання дітей підліткового та юнацького віку. Інноваційна педагогіка. Одеса, 2021. Випуск 32. Т. 1. С. 181-183. URL: http://www.innovpedagogy.od.ua/archives/2021/32/part_1/41.pdf (дата звернення: 08.04.2021).
} 
1. Technology of social education «Steps to Your Health» aimed at the development, formation of health-preserving competence of adolescents and young adults ${ }^{9}$.

2.Technology of forming a healthy lifestyle using the method of "Peer-to-Peer» aimed at the development, formation of health-preserving, communicative, legal, and vital competencies of adolescents and young adults $^{10}$.

3. Technology of social education «Personal dignity. Safety of life. Civic position» aimed at the development, formation of vital, communicative, legal, social, economic, and leisure competencies of adolescents and their parents ${ }^{11}$.

4. Technology of social education "Profession. Education. Career. Success» aimed at the development, formation of social competence of adolescents and young adults ${ }^{12}$.

5. Technology of social and financial education and upbringing «We create the future responsibly and sparingly» aimed at the development, formation of vital, social, legal, economic competencies of young children ${ }^{13}$.

6. Technology of social education «Changing life» aimed at the development, formation of health-preserving, communicative, vital,

\footnotetext{
${ }^{9}$ Сушик, Н. Компетентнісний підхід у реалізації технології формування здорового способу життя дітей підліткового та юнацького віку з використанням методу «рівний - рівному». Нова педагогічна думка. Рівне, 2019. № 4 (100). C. 93-95. URL: http://nbuv.gov.ua/UJRN/Npd_2019_4_21 (дата звернення: 08.04.2021).

${ }_{10}$ Сушик, Н. Компетентнісний підхід у реалізації технології соціального виховання «Особиста гідність. Безпека життя. Громадянська позиція» дітей підліткового та юнацького віку. Нова педагогічна думка. Рівне, 2020. № 2 (102). С. 162-167. URL: http://nbuv.gov.ua/UJRN/Npd_2020_2_37 (дата звернення: 08.04.2021).

${ }_{11}$ SushykNataliiaCompetentapproachtorealizationoftechnologyofsocialeducationofpersonality. Innovative ApproachestoEnsuringtheQualityofEducation, ScientificResearchandTechnologicalProcesses : monograph / editedby Magdalena Gawron-Łapuszek, YanaSuchukova. Katowice: PublishingHouseofUniversity of Technology, 2021. P. 900-902, 1219. URL: http://www.wydawnictwo.wst.pl/uploads/ files/3ae54f97de8a1480cfb229660e616f25.pdf (дата звернення: 08.04.2021)

12 SushykNataliiaCompetentapproachtorealizationoftechnologyofsocialeducationofpersonality. Innovative ApproachestoEnsuringtheQualityofEducation, ScientificResearchandTechnologicalProcesses : monograph / editedby Magdalena Gawron-Łapuszek, YanaSuchukova. Katowice: PublishingHouseofUniversity of Technology, 2021. P. 903-906, 1219. URL: http://www.wydawnictwo.wst.pl/uploads/files/ 3ae54f97de8a1480cfb229660e616f25.pdf (дата звернення: 08.04.2021)

13 SushykNataliiaCompetentapproachtorealizationoftechnologyofsocialeducationofpersonality. Innovative ApproachestoEnsuringtheQualityofEducation, ScientificResearchandTechnologicalProcesses : monograph / editedbyMagdalena Gawron-Łapuszek, YanaSuchukova. Katowice: PublishingHouseof UniversityofTechnology, 2021. P. 903-906, 1219. URL: http://www.wydawnictwo.wst.pl/ uploads/files/3ae54f97de8a1480cfb229660e616f25.pdf (дата звернення: 08.04.2021)
} 
economic, social competencies of children and parents who are in difficult life circumstances or have the highest risk of getting into them (see table).

Table

$$
\begin{aligned}
& \text { Characteristics of the social education technology } \\
& \text { «Changing the lives» of children and parents who are in difficult life } \\
& \text { circumstances or have the highest risk of getting into them, } \\
& \text { which is based on the competence approach }
\end{aligned}
$$

\begin{tabular}{|c|c|c|c|}
\hline № & $\begin{array}{l}\text { Components of } \\
\text { technology }\end{array}$ & \multicolumn{2}{|c|}{ Characteristics of technology components } \\
\hline 1. & $\begin{array}{c}\text { Object of } \\
\text { technology }\end{array}$ & \multicolumn{2}{|c|}{$\begin{array}{c}\text { Children and parents who are in difficult life circumstances or have the } \\
\text { highest risk of getting into them. }\end{array}$} \\
\hline 2. & $\begin{array}{c}\text { Subjects of } \\
\text { technology } \\
\text { implementation }\end{array}$ & \multicolumn{2}{|c|}{$\begin{array}{l}\text { Social managers, social work specialists, social workers, social } \\
\text { pedagogues. }\end{array}$} \\
\hline 3. & $\begin{array}{l}\text { The purpose of } \\
\text { technology }\end{array}$ & \multicolumn{2}{|c|}{$\begin{array}{c}\text { Development, formation of children and parents competencies, who are } \\
\text { in difficult life circumstances or have the highest risk of getting into } \\
\text { them. }\end{array}$} \\
\hline 4. & $\begin{array}{l}\text { The task of } \\
\text { technology }\end{array}$ & \multicolumn{2}{|c|}{$\begin{array}{l}\text { Formation of children and parents competencies (health-preserving, } \\
\text { communicative, vital, economic, social), who are in difficult life } \\
\text { circumstances or have the highest risk of getting into them. }\end{array}$} \\
\hline \multirow{9}{*}{5.} & \multirow[t]{9}{*}{$\begin{array}{l}\text { The structure of } \\
\text { technology }\end{array}$} & \multicolumn{2}{|c|}{$\begin{array}{l}\text { The structure of the technology for children and parents, who are in } \\
\text { difficult life circumstances or have the highest risk of getting into them: }\end{array}$} \\
\hline & & \multicolumn{2}{|c|}{ Module 1. «Changing lives: learn to be healthy». } \\
\hline & & \multicolumn{2}{|c|}{ Module 2. «Changing lives: manage stress». } \\
\hline & & Module 3 & «Changing lives: break the circle of anger». \\
\hline & & \multirow{2}{*}{\multicolumn{2}{|c|}{$\begin{array}{l}\text { Module 4. «Changing lives: raise children without punishment». } \\
\text { Module 5. «Changing lives: learn to communicate effectively». }\end{array}$}} \\
\hline & & & \\
\hline & & \multicolumn{2}{|c|}{ Module 6. «Changing lives: a defender of himself». } \\
\hline & & \multicolumn{2}{|c|}{ Module 7. «Changing lives: make decisions». } \\
\hline & & \multicolumn{2}{|c|}{ Module 8. «Changing lives: manage the budget». } \\
\hline & $\begin{array}{l}\text { Content of } \\
\text { technology }\end{array}$ & \multicolumn{2}{|c|}{$\begin{array}{l}\text { 1) health-preserving competence formation of children and parents, } \\
\text { who are in difficult life circumstances or have the highest risk of } \\
\text { getting into them: }\end{array}$} \\
\hline & \multirow{3}{*}{$\begin{array}{l}\text { Module } 1 . \\
\text { «Changing lives: } \\
\text { learn to be } \\
\text { healthy» }\end{array}$} & value & health \\
\hline & & value orientation & $\begin{array}{l}\text { development, strengthening, preservation, } \\
\text { restoration of health }\end{array}$ \\
\hline 6. & & knowledge & $\begin{array}{l}\text { essence and components (physical, mental, } \\
\text { spiritual, social) of health; subjective health factors: } \\
\text { self-love, stable belief system, optimism, ability to } \\
\text { periodically work at the limit of their capabilities, } \\
\text { quickly adapt to changing social conditions, in } \\
\text { particular, life circumstances, prevent, respond } \\
\text { quickly to stress, recover from it, regulate } \\
\text { emotions, feelings, behave with dignity; optimal } \\
\text { health and a healthy lifestyle; factors for achieving } \\
\text { optimal health: a stable system of values, value } \\
\text { orientations, positive thinking, physical activity, } \\
\text { healthy eating, sleeping, quality medical care, full- }\end{array}$ \\
\hline
\end{tabular}




\begin{tabular}{|c|c|c|}
\hline & & $\begin{array}{l}\text { fledged hygiene, clean ecological environment of } \\
\text { the individual; features of healthy nutrition: quality, } \\
\text { regularity, diversity, energy, enzyme adequacy, } \\
\text { safety, satisfaction; principles, components, } \\
\text { planning and implementation of healthy eating; } \\
\text { WHO recommendations on levels of physical } \\
\text { activity for health, taking into account age, } \\
\text { individual personality traits. }\end{array}$ \\
\hline & attitude & children and parents responsible attitude to health \\
\hline & $\begin{array}{l}\text { experience, } \\
\text { skills }\end{array}$ & $\begin{array}{l}\text { following a healthy lifestyle, taking into account } \\
\text { the age, individual characteristics of children and } \\
\text { parents }\end{array}$ \\
\hline & ability & $\begin{array}{c}\text { to achieve the full physical, mental, spiritual, } \\
\text { social well-being of children and parents }\end{array}$ \\
\hline Module 2 & value & mental health \\
\hline $\begin{array}{l}\text { «Changing lives: } \\
\text { manage stress» }\end{array}$ & value orientation & $\begin{array}{l}\text { development, strengthening, preservation, } \\
\text { restoration of mental health }\end{array}$ \\
\hline & knowledge & $\begin{array}{l}\text { essence, signs, causes, stages, effects of stress; } \\
\text { essence, level of stress resistance; methods, } \\
\text { techniques, means of emotional self-regulation, } \\
\text { feelings, personality behavior in order to prevent } \\
\text { and overcome stress; signs of stress in different } \\
\text { ages children, recommendations for parents to } \\
\text { prevent and overcome stress in children }\end{array}$ \\
\hline & attitude & $\begin{array}{c}\text { children' and parents' responsible attitudes towards } \\
\text { mental health }\end{array}$ \\
\hline & $\begin{array}{l}\text { experience, } \\
\text { skills }\end{array}$ & $\begin{array}{l}\text { do self-regulation of emotions, feelings, personality } \\
\text { behavior in order to prevent and overcome stress at } \\
\text { children and parents }\end{array}$ \\
\hline & ability & $\begin{array}{l}\text { to achieve the mental wellbeing of children and } \\
\text { parents }\end{array}$ \\
\hline Module 3. & value & \begin{tabular}{|l} 
social health \\
\end{tabular} \\
\hline $\begin{array}{l}\text { «Changing lives: } \\
\text { break the circle of }\end{array}$ & value orientation & $\begin{array}{l}\text { development, strengthening, preservation, } \\
\text { restoration of social health }\end{array}$ \\
\hline anger» & knowledge & $\begin{array}{l}\text { nature, types, signs of domestic abuse; myths about } \\
\text { domestic violence against children; causes and } \\
\text { consequences of domestic violence against } \\
\text { children; recommendations for the prevention of } \\
\text { domestic violence }\end{array}$ \\
\hline & attitude & $\begin{array}{l}\text { children' and parents' responsible attitudes towards } \\
\text { social health }\end{array}$ \\
\hline & $\begin{array}{l}\text { experience, } \\
\text { skills }\end{array}$ & $\begin{array}{c}\text { behave with dignity in a family that is in difficult } \\
\text { life circumstances }\end{array}$ \\
\hline & ability & $\begin{array}{c}\text { to achieve the social wellbeing of children and } \\
\text { parents }\end{array}$ \\
\hline $\begin{array}{l}\text { Module } 4 . \\
\text { «Changing lives: } \\
\text { raise children }\end{array}$ & $\begin{array}{l}\text { 2) social compe } \\
\text { difficult life cir }\end{array}$ & $\begin{array}{l}\text { nce formation of parents and children who are in } \\
\text { umstances or have the highest risk of getting into } \\
\text { them: }\end{array}$ \\
\hline without & value & parenthood \\
\hline punishment» & value orientation & responsible, competent parenting \\
\hline & knowledge & $\begin{array}{l}\text { essence, stages, features of children's socialization; } \\
\text { crisis periods (three, six or seven years, } \\
\text { adolescence) of children; parental stereotypes about }\end{array}$ \\
\hline
\end{tabular}




\begin{tabular}{|c|c|c|}
\hline & & $\begin{array}{l}\text { raising children; purpose, tasks, principles, styles } \\
\text { (democratic, authoritarian, liberal), methods, } \\
\text { techniques, means of raising children }\end{array}$ \\
\hline & attitude & $\begin{array}{l}\text { personal responsibility for development, formation } \\
\text { of parental competence }\end{array}$ \\
\hline & $\begin{array}{l}\text { experience, } \\
\text { skills }\end{array}$ & $\begin{array}{l}\text { optimally and effectively apply methods, } \\
\text { techniques, means of education taking into account } \\
\text { the age and individual characteristics of children }\end{array}$ \\
\hline & ability & effectively raise children \\
\hline $\begin{array}{l}\text { Module 5. } \\
\text { «Changing lives: } \\
\text { learn to }\end{array}$ & $\begin{array}{l}\text { 3) communicative } \\
\text { are in difficult li }\end{array}$ & $\begin{array}{l}\text { competence formation of children and parents who } \\
\text { e circumstances or have the highest risk of getting } \\
\text { into them: }\end{array}$ \\
\hline communicate & value & communication \\
\hline effectively» & value orientation & effective communication \\
\hline & knowledge & $\begin{array}{l}\text { essence and principles of effective communication, } \\
\text { algorithm of constructive criticism; types and } \\
\text { conditions of choosing the optimal distance in } \\
\text { communication; essence and means of nonverbal } \\
\text { communication (facial expressions, pantomime), } \\
\text { types, features, content of gestures, posture, ways } \\
\text { of the interlocutor; essence, prevention and } \\
\text { overcoming of barriers in communication; } \\
\text { recommendations for effective communication with } \\
\text { introverts and extroverts; essence, types, methods } \\
\text { of active listening; characteristics and conditions of } \\
\text { effective application of five strategies (rivalry, } \\
\text { avoidance, adaptation, compromise, cooperation) } \\
\text { of behavior in conflicts; types and algorithm of } \\
\text { drawing up of the citizens address, stages of } \\
\text { communication, code of behavior at expert } \\
\text { reception }\end{array}$ \\
\hline & attitude & $\begin{array}{l}\text { effective communication depends on the level of } \\
\text { individual communicative competence }\end{array}$ \\
\hline & $\begin{array}{l}\text { experience, } \\
\text { skills }\end{array}$ & $\begin{array}{l}\text { implement the principles, stages of communication; } \\
\text { use verbal and nonverbal means (facial } \\
\text { expressions, pantomime, distance) of } \\
\text { communication; actively listen to the interlocutor; } \\
\text { apply five behavioral strategies to prevent and } \\
\text { constructively resolve conflicts; communicate } \\
\text { effectively with social workers and other officials }\end{array}$ \\
\hline & ability & $\begin{array}{c}\text { communicate effectively with people in different } \\
\text { life situations }\end{array}$ \\
\hline $\begin{array}{c}\text { Module } 6 . \\
\text { «Changing lives: a } \\
\text { defender of }\end{array}$ & $\begin{array}{l}\text { 4) life compete } \\
\text { difficult life cir }\end{array}$ & $\begin{array}{l}\text { ice formation of children and parents who are in } \\
\text { umstances or have the highest risk of getting into } \\
\text { them: }\end{array}$ \\
\hline himself» & value & life \\
\hline & value orientation & Safe life \\
\hline & knowledge & $\begin{array}{l}\text { safety and danger for children, norms and rules of } \\
\text { safe behavior with different people; } \\
\text { recommendations for safe behavior of children on } \\
\text { the Internet, at school, at the entrance hall, at home, } \\
\text { on the street }\end{array}$ \\
\hline & attitude & responsibility of parents and children for the safety \\
\hline
\end{tabular}




\begin{tabular}{|c|c|c|c|}
\hline & & & of their life and health \\
\hline & & $\begin{array}{l}\text { experience, } \\
\text { skills }\end{array}$ & safe behavior in various life situations \\
\hline & & ability & $\begin{array}{c}\text { behave responsibly, safely in various life } \\
\text { circumstances }\end{array}$ \\
\hline & Module 7. & value & $\begin{array}{c}\text { life experience } \\
\end{array}$ \\
\hline & «Changing lives: & value orientation & gain quality life experience \\
\hline & make decisions» & knowledge & $\begin{array}{l}\text { simple and complex situations, factors influencing } \\
\text { the choice, decision-making, decision-making } \\
\text { algorithm using methods («brainstorming», «traffic } \\
\text { light rule», «Descartes Square»); five types of } \\
\text { personality behavior in decision making; } \\
\text { recommendations for making effective decisions }\end{array}$ \\
\hline & & attitude & $\begin{array}{l}\text { personal responsibility for decision making and its } \\
\text { results }\end{array}$ \\
\hline & & $\begin{array}{c}\text { experience, } \\
\text { skills }\end{array}$ & make and implement effective decisions \\
\hline & & ability & $\begin{array}{c}\text { make and implement effective decisions in } \\
\text { difficult life circumstances }\end{array}$ \\
\hline & $\begin{array}{l}\text { Module } 8 . \\
\text { «Changing lives: } \\
\text { manage the }\end{array}$ & $\begin{array}{l}\text { 5) economic con } \\
\text { in difficult life ct }\end{array}$ & $\begin{array}{l}\text { petence formation of children and parents who are } \\
\text { cumstances or have the highest risk of getting into } \\
\text { them: }\end{array}$ \\
\hline & budget» & value & welfare \\
\hline & & value orientation & $\begin{array}{c}\text { welfare wellbeing } \\
\end{array}$ \\
\hline & & knowledge & $\begin{array}{l}\text { essence, principles of financial planning; types of } \\
\text { the person / family financial plans, algorithm of the } \\
\text { financial plan development: definition of needs and } \\
\text { the purposes; income and expense analysis; } \\
\text { analysis of the efficiency of asset use; analysis of } \\
\text { loans and debts; insurance protection analysis; } \\
\text { personal / family budget development; adjustment } \\
\text { of the person / family financial plan; an effective } \\
\text { method of the «rule of four envelopes» of personal } \\
\text { / family budget formation; recommendations for } \\
\text { saving personal / family budget }\end{array}$ \\
\hline & & attitude & $\begin{array}{c}\text { personal responsibility for the family financial } \\
\text { support }\end{array}$ \\
\hline & & $\begin{array}{l}\text { experience, } \\
\text { skills }\end{array}$ & $\begin{array}{l}\text { definition of financial goals; planning and drawing } \\
\text { up a personal and family budget; earning, rational } \\
\text { spending, saving money to achieve their goals; own } \\
\text { finances management }\end{array}$ \\
\hline & & ability & $\begin{array}{c}\text { responsibly use financial resources to achieve } \\
\text { the well-being of the family }\end{array}$ \\
\hline 7. & $\begin{array}{c}\text { Forms of } \\
\text { technology } \\
\text { implementation }\end{array}$ & Group forms o & $\begin{array}{l}\text { the individual social education: training, training } \\
\text { sessions }\end{array}$ \\
\hline 8 . & $\begin{array}{l}\text { Methods of } \\
\text { technology } \\
\text { implementation }\end{array}$ & $\begin{array}{r}\text { Methods of the i1 } \\
\text { message, brainst } \\
\text { grc }\end{array}$ & $\begin{array}{l}\text { dividual social education: conversation, information } \\
\text { rming, discussion, attitude, example, work in small } \\
\text { aps, method of exercises, case method }\end{array}$ \\
\hline 9. & $\begin{array}{l}\text { 1. Project «Ch } \\
\text { the conflict in } \mathrm{Ukr}\end{array}$ & $\begin{array}{l}\text { Educational and } r \\
\text { itable assistance to } \\
\text { ne». Kyiv : all-Ukr }\end{array}$ & $\begin{array}{l}\text { ethodical support of technology } \\
\text { IDPs and the most vulnerable families affected by } \\
\text { inian charitable organization «Ukrainian Child }\end{array}$ \\
\hline
\end{tabular}




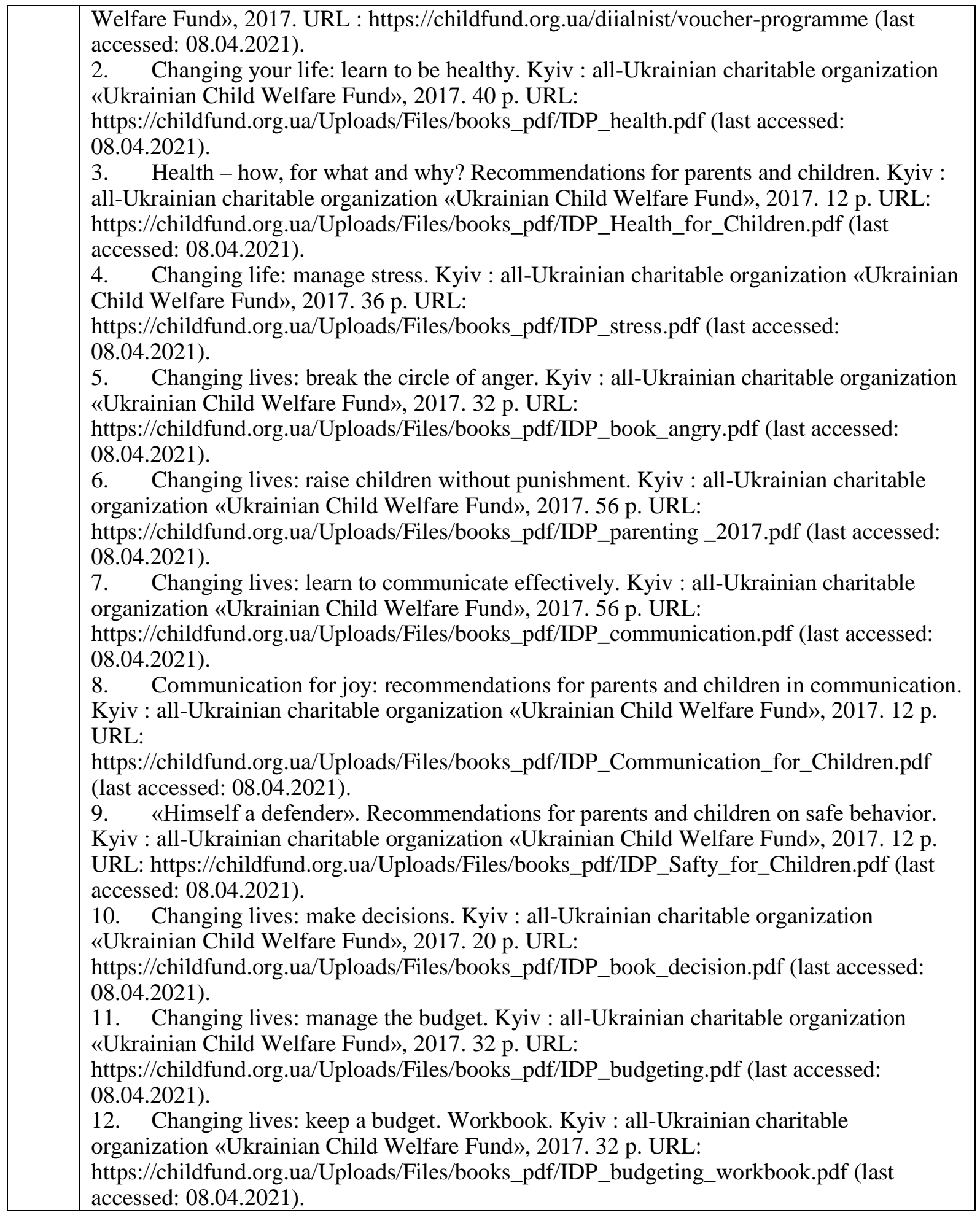

\section{CONCLUSIONS}

Technologies of social upbringing of children and parents who are in difficult life circumstances or have the highest risk of getting into them, are characterized by the following features: 1) purposefulness; 
2) conceptuality; 3) standardization; 4) interactivity; 5) diagnostics;

6) manageability; 7) controllability; 8) effectiveness; 9) optimality.

Substantiated technologies of children and parents social education on the basis of the competence approach should be implemented in compliance with the following conditions:

1) partnership interaction of social managers, social work specialists, social workers, social pedagogues, parents and children;

2) taking into account the socio-demographic and individual characteristics of the target group;

3) diagnostics of the level of participants' competencies formation at the initial and final stage of technology implementation;

4) use of interactive group forms of social work (video lectures), trainings (training classes), classes with the use of educational and preventive board games);

5) application of effective methods of the individual social education (conversation, information message, brainstorming, discussion, persuasion, example, work in small groups, the method of exercises, the case method);

6) regularity, optimal duration, frequency of technology application with the target group;

7) high-quality educational and methodical, material and technical support of various forms and methods of social work with the target group.

The result of the certain technologies application of children and parents social education who are in difficult life circumstances or have the highest risk of getting into them, is the formation of competent individuals who can successfully manage their lives, get a quality education, get a job, build a professional career, communicate effectively, work in a professional team, create a prosperous family, responsibly, competently raise children, achieve physical, mental, spiritual, social, financial wellbeing.

\section{SUMMARY}

The article identifies the essence, features of the family as a microfactor of children and parents socialization. It is substantiated that under the influence of unfavorable socialization factors, children and parents are in difficult life circumstances or have the highest risk of getting into them. Based on the study of domestic legislation, a list of families, parents, children who are in difficult life circumstances or have the highest 
risk of getting into them and need to carry out various types of professional social work with them to prevent and overcome such circumstances, including: 1) social integration; 2) social adaptation; 3) social education; 4) social support; 5) social counseling; 6) social prevention; 7) social mediation (mediation); 8) social rehabilitation and others. Based on the results of studying the scientific literature, domestic experience of social work with families, children and youth, the essence, structure, content of health-preserving, vital, communicative, legal, economic, social competencies of the individual are determined. The development, formation of an integrated set of personal competencies in the implementation of technologies of children and parents social education is substantiated. The subjects, object, purpose, tasks, structure, content, forms, methods of implementation of the social education technology "Changing the life» of children and parents who are in difficult life circumstances or have the highest risk of getting into them, based on the competence approach are defined.

\section{REFERENCES}

1. Sushyk Nataliia Competent approach to realization of technology of social education of personality. Innovative Approaches to Ensuring the Quality of Education, Scientific Research and Technological Processes : monograph / edited by Magdalena Gawron-Łapuszek, Yana Suchukova. Katowice : Publishing House of University of Technology, 2021. P. 893916, 1219. URL: http://www.wydawnictwo.wst.pl/uploads/files/3ae54f97 de8a1480cfb229660e616f25.pdf (дата звернення: 08.04.2021)

2. Порядок організації надання соціальних послуг, затверджений постановою Кабінету Міністрів України від 1 червня 2020 р. № 587. URL: https://zakon.rada.gov.ua/laws/show/587-2020-\%D0\%BF\#n10 (дата звернення: 18.04.2021).

3. Про соціальні послуги: Закон України від 17.01.2019 р. № 2671VIII. URL: https://zakon.rada.gov.ua/laws/show/2671-19\#n482 (дата звернення: 18.04.2021)

4. Про соціальну роботу з сім'ями, дітьми та молоддю: Закон України від 17.01.2019 p. № 2671-VIII. URL: https://zakon.rada.gov.ua/laws/show/2558-14\#Text (дата звернення: 18.04.2021). 
5. Проект «Благодійна допомога ВПО та найбільш вразливим родинам, які постраждали внаслідок конфлікту в Україні». Київ : ВБО «Український фонд Благополуччя дітей»«, 2017. URL: https://childfund.org.ua/diialnist/voucher-programme (дата звернення: 08.04.2021).

6. Сушик Н. С. Формування здоров'язбережувальної компетентності особистості у реалізації технологій соціального виховання дітей підліткового та юнацького віку. Інновачійна педагогіка. Одеса, 2021. Випуск 32. Т. 1. С. 180-183. URL: http://www.innovpedagogy.od.ua/archives/2021/32/part_1/41.pdf (дата звернення: 08.04.2021).

7. Сушик, Н. Компетентнісний підхід у реалізації технології соціального виховання «Особиста гідність. Безпека життя. Громадянська позиція» дітей підліткового та юнацького віку. Нова педагогічна думка. Рівне, 2020. № 2 (102). С. 161-167. URL: http://nbuv.gov.ua/UJRN/Npd_2020_2_37 (дата звернення: 08.04.2021).

8. Сушик, Н. Компетентнісний підхід у реалізації технології формування здорового способу життя дітей підліткового та юнацького віку $з$ використанням методу «рівний - рівному». Нова педагогічна думка. Рівне, 2019. № 4 (100). C. 91-95. URL: http://nbuv.gov.ua/UJRN/Npd_2019_4_21 (дата звернення: 08.04.2021).

Information about the authors: Sushyk N. S. Candidate of Pedagogical Sciences, Associate Professor, Associate Professor at the Department of Social Work and Pedagogy of the Higher School, Lesya Ukrainka Volyn National University 13 Voli ave., Lutsk, Volyn region, 43025, Ukraine

Karpinska N. V. Candidate of Law Sciences, Associate Professor at the Department of Criminal Law and Procedure, Associate Professor at the Department of Civil and Juridical Disciplines, Lesya Ukrainka Volyn National University 13 Voli ave., Lutsk, Volyn region, 43025, Ukraine 